\title{
Volcanoes magnify Metro Manila's southwest monsoon rains and lethal floods
}

\author{
Alfredo Mahar F. Lagmay ${ }^{1 *}$, Gerry Bagtasa ${ }^{2}$, Irene A. Crisologo ${ }^{1}$, Bernard Alan B. Racoma ${ }^{1}$ and \\ Carlos Primo C. David ${ }^{1}$
}

${ }^{1}$ National Instiute of Geological Sciences, University of the Philippines, Quezon City, Philippines

2 Institute of Environmental Sciences and Meteorology, University of the Philippines, Quezon City, Philippines

\section{Edited by:}

Valerio Acocella, Università Roma

Tre, Italy

\section{Reviewed by:}

Alexandre M. Ramos, University of Lisbon, Portugal

Ana María Durán-Quesada,

University of Costa Rica, Costa Rica

*Correspondence:

Alfredo Mahar F. Lagmay, National Institute of Geological Sciences,

University of the Philippines Diliman, P.Velasquez Street, Diliman, Quezon City 1101, Metro Manila, Philippines e-mail:mlagmay@nigs.upd.edu.ph; mlagmay@noah.dost.gov.ph
Many volcanoes worldwide are located near populated cities that experience monsoon seasons, characterized by shifting winds each year. Because of the severity of flood impact to large populations, it is worthy of investigation in the Philippines and elsewhere to better understand the phenomenon for possible hazard mitigating solutions, if any. During the monsoon season, the change in flow direction of winds brings moist warm air to cross the mountains and volcanoes in western Philippines and cause lift into the atmosphere, which normally leads to heavy rains and floods. Heavy southwest monsoon rains from 18-21 August 2013 flooded Metro Manila (population of 12 million) and its suburbs paralyzing the nation's capital for an entire week. Called the 2013 Habagat event, it was a repeat of the 2012 Habagat or extreme southwest monsoon weather from 6-9 August, which delivered record rains in the mega city. In both the 2012 and 2013 Habagat events, cyclones, the usual suspects for the delivery of heavy rains, were passing northeast of the Philippine archipelago, respectively, and enhanced the southwest monsoon. Analysis of Doppler data, rainfall measurements, and Weather Research and Forecasting (WRF) model simulations show that two large stratovolcanoes, Natib and Mariveles, across from Manila Bay and approximately $70 \mathrm{~km}$ west of Metro Manila, played a substantial role in delivering extreme rains and consequent floods to Metro Manila. The study highlights how volcanoes, with their shape and height create an orographic effect and dispersive tail of rain clouds which constitutes a significant flood hazard to large communities like Metro Manila.

Keywords: weather research and forecasting, extreme monsoon, orographic effects, weather doppler radar, extreme rainfall, volcanic hazards, flooding

\section{INTRODUCTION}

Monsoons are seasonal shifts in the wind pattern that bring abundant rain and thunderstorms during one season and drought in another. They happen in several locations all over the world including: North America, South America, Asia and Africa with the most famous monsoons occurring in India, Bangladesh, South China Sea, Mexico, and Southwest United States (Hales, 1974; Lau et al., 2000; Holton et al., 2003; Kripalani et al., 2003; NOAA, 2004; Ahasan et al., 2010). The wind shift during the monsoon season brings warm moist air into mountain ranges near the coasts of continental landmasses and islands, which cause rapid uplift that lead to heavy rains (Whiteman, 2000) and floods inland (Crimmins, 2006).

The southwest monsoon, or locally known in the Philippines as Habagat, is a natural weather pattern that occurs during the months from June to September in the Asian subcontinent. The Habagat is characterized by warm and humid climate and occurs when warm moist air flows over the country from the southwest. It is a weather phenomenon also responsible for bringing significant rainfall from May to October each year and which can cause heavy rainfall that may last for several days or weeks at a time affecting the Philippine archipelago's western section (PAGASA, 2013).

In 2012 during the Habagat season, monsoon rains brought widespread flooding that swamped the country's capital Metro Manila (Figure 1). This made a repeat in 2013 where similar areas along the metropolis were heavily flooded. Lacking names because names for extreme weather events are only given to tropical cyclones in the Philippines, the two consecutive-years of extreme flooding have been referred to as the "2012 and 2013 Habagat Floods."

The 2012 Habagat event mainly affected the northern part of Metro Manila where $1007.4 \mathrm{~mm}$ of rain fell from August 6 to 10, 2012, $363.7 \mathrm{~mm}$ of which fell on August 8 alone (Science Garden Station, PAGASA). On the other hand, the Habagat 2013 event also affected the southern part of Greater Metro Manila (Cavite and Laguna provinces) which recorded a total of $1,067.4 \mathrm{~mm}$ from August 18-22, 2013, with a one-day maximum rain event of $235.97 \mathrm{~mm}$ occurring on August 21, 2013 (Sangley Point, PAGASA). The rainfall recorded by the northern Science Garden Station for Habagat 2013 was $8 \%$ more than the average for the month of August (red dashed line) and $85 \%$ less than the recorded 

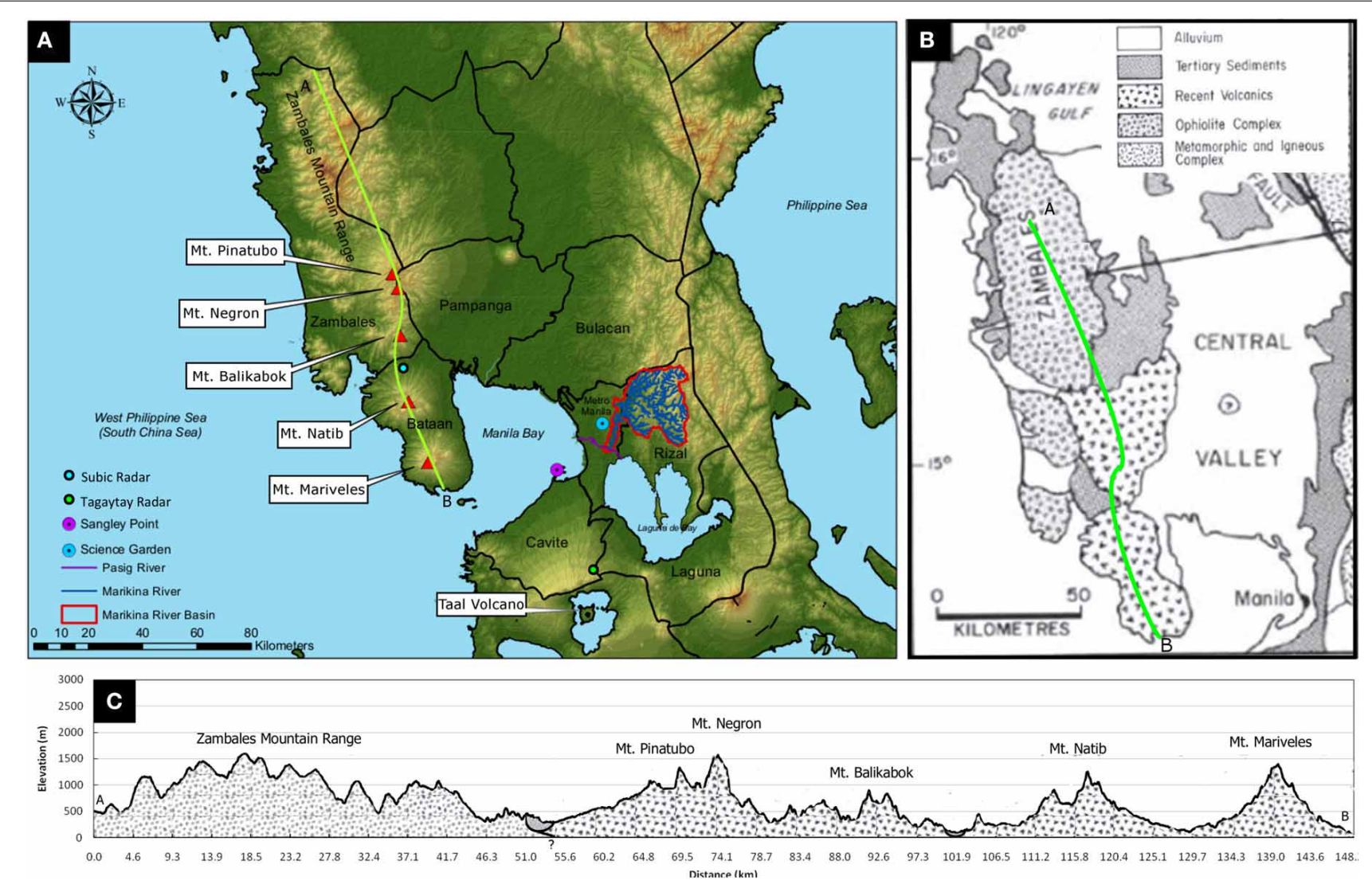

FIGURE 1 | (A) Elevation map of Metro Manila and surrounding provinces. Shown in the map is the Zambales Mountain Range and the volcanoes Pinatubo, Negron, Balikabok, Natib, and Mariveles (red triangles). The Subic Radar (blue dot) is situated along the Zambales Mountain range. The Marikina River watershed east of Metro Manila is shown in red outline, with blue-colored drainage network. The Marikina and Pasig
Rivers are main drainage systems in Metro Manila connected to the Marikina Watershed. (B) Generalized geologic map of the Zambales range (modified from Hutchison, 1989). The transect for the profile in (C) is shown as a green line. (C) Profile and generalized geology of the Zambales Range showing Mt. Balikabok, Mt. Negron, and Mt. Pinatubo and their corresponding elevations. rainfall for Habagat 2012 (blue dotted line) while the Sangley Point Station recorded 125\% more than the August average (red dashed line) and 36\% more than the rainfall recorded for Habagat 2012 (blue dotted line) (see Figure 2).

The one day maximum rains during the Habagat 2012 and 2013 are near the daily maximum rains of the fatal Tropical storm Ketsana (448.5 mm) (Lagmay et al., 2010; Abon et al., 2011) and Hurricane Katrina (417 mm) (Knabb et al., 2005; Roth, 2008) events, which devastated Metro Manila and New Orleans, respectively. While Tropical storm Ketsana and Hurricane Katrina are both cyclone events, Habagat 2012 and 2013 are simply enchanced monsoon events, and as such, no typhoon warnings were raised.

According to the National Disaster Risk Reduction Council (NDRRMC, 2012), the 2012 Habagat event resulted in 109 fatalities in 17 provinces, most casualties due to drowning. Property damage went as high as $\mathrm{PhP} 3$ billion ( $\mathrm{PhP}=$ Philippine Peso), with $\mathrm{PhP} 651.3$ million (US\$ 14.6 million) for infrastructure and PhP 2.4 billion (US\$ 53.9 million) in agriculture. For 2013, the Habagat event saw 27 fatalities in 12 provinces of northern Philippines. One person died in Metro Manila, whereas property damage as of NDRRMC's situation report was estimated at PhP 688.1 million (US\$15.4 million), including PhP 137.9 million (US\$3.1 million) in infrastructure and $\mathrm{PhP} 550.2$ million (US\$12.3 million) in agriculture (NDRRMC, 2013).

This study investigates the rainfall distribution in Greater Metro Manila and how two volcanoes, Mt. Natib and Mt. Mariveles, magnified and focused the rains of the southwest monsoon during the 2012 and 2013 Habagat events. These two large and potentially active stratovolcanoes (Phivolcs, 2013) are located approximately $70 \mathrm{~km}$ west of Metro Manila. During the Habagat season in 2012 and 2013, both acted as a barrier for the flow of warm moist air from the West Philippine Sea (also known as South China Sea) (Figure 1A). The orography of the volcanoes leads to air mass rising rapidly on the lee side causing rain cloud formation that brought extreme precipitation and massive floods to Metro Manila.

The severity of flood impact brought by the southwest monsoon rains to large populations warrants further investigation in the Philippines and elsewhere. In 1950, the core municipality of Manila had a population under 1 million and represented approximately 60 percent of residents in the Nation's Capital. Manila has 

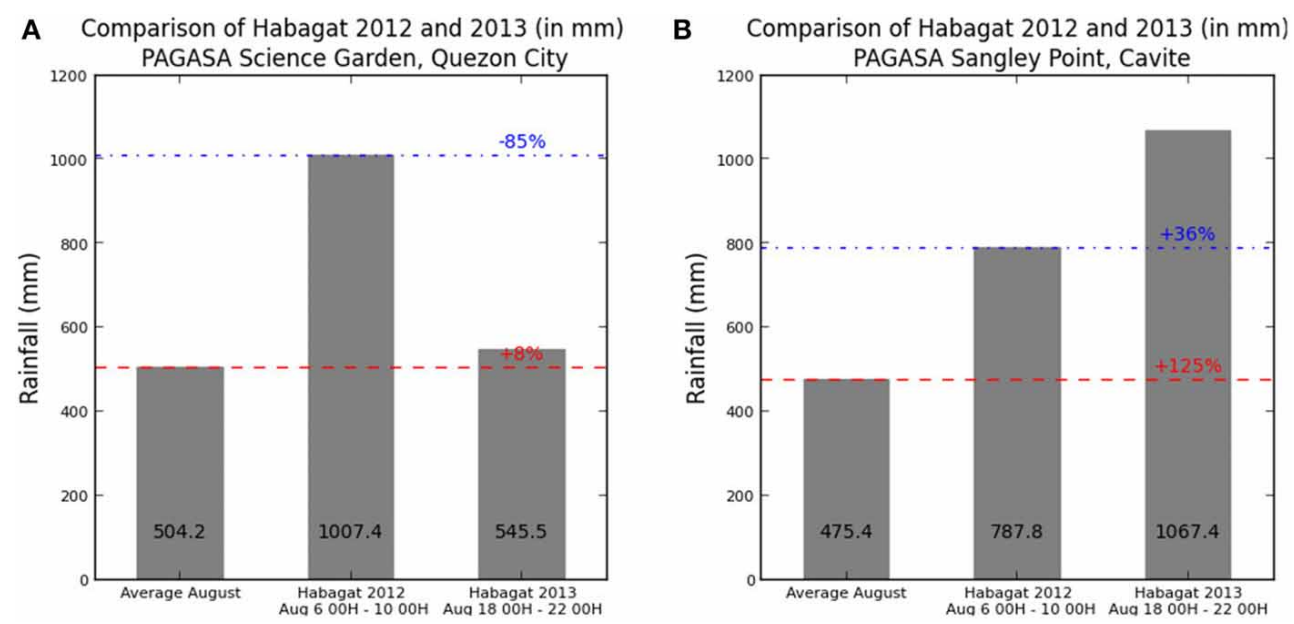

FIGURE 2 | (A) ARG data from Science Garden Station (B) ARG data from Sangley Point Station. Habagat 2012 is taken from August $0600 \mathrm{H}$ to $1000 \mathrm{H}, 2012$ while Habagat 2013 is taken on August $1800 \mathrm{H}-22$ 00H, 2013.

expanded into a sprawling metropolis area called Greater Metro Manila that extends to the provinces of Rizal, Cavite, Laguna, Bulacan and Batangas with a total population estimated at 26.5 million people in 2010 and expected to rapidly expand to about 45-50 million people by 2050 (Cox, 2011). Since many volcanoes worldwide are situated in the monsoon belt and proximal to populated areas, it is necessary to understand the monsoon phenomenon and its interaction with volcanic edifices with the aim to come up with possible mitigating solutions to this type of hazard.

\section{GEOGRAPHICAL AND GEOLOGICAL SETTING \\ 2.1. WATERSHEDS OF METRO MANILA AND SUBURBS}

Metro Manila is located on an isthmus between two bodies of water, Manila Bay, which opens to the West Philippine Sea and Laguna de Bay (Figure 1A), a $10 \times 20 \mathrm{~km}$ wide freshwater lake partly formed by two calderagenic eruptions. The metropolis lies on one of the widest floodplains in the Philippines underlain by mostly volcanic and coastal sediments (Lagmay et al., 2010).

To the east of Metro Manila is the Marikina River Basin $\left(582 \mathrm{~km}^{2}\right)$ (Abon et al., 2011), which drains into a highly urbanized portion of the metropolis. The Marikina River joins the Pasig River, and drains directly toward Manila Bay and Laguna de Bay. These rivers serve as the main outlet for tributaries of the Marikina River Basin (Figure 1).

South of Metro Manila is Cavite Province, located within the watershed on the northern slopes of Ancestral Taal Volcano. North of Metro Manila is Bulacan Province which in part is within the La Mesa watershed and in part the Pampanga watershed, a large $10,707.95 \mathrm{~km}^{2}$ river basin composed of 7 major tributaries that drain toward north Manila Bay (Figure 1A).

\subsection{ZAMBALES MOUNTAIN RANGE}

The Zambales Range is a chain of mountains composed of an Ophiolite Complex, Tertiary sediments and volcanic deposits. The mountain range separates the central Luzon plain from the West Philippine Sea (Figure 1B). The Ophiolite Complex is composed of an igneous stratigraphic sequence of residual peridotite, dunite, cumulate peridotites, gabbro, sheeted dike complexes, pillow basalts and Upper Eocene to mid-Oligocene pelagic sediments. This coherent ophiolite mass is a segment of a stretch of ridges and troughs, which along with a chain of volcanoes that extends southward to Manila Bay, define the western physiographic province of the Philippine Archipelago (Lagmay, 1993).

\subsection{CENTRAL LUZON VOLCANIC ARC}

Directly across Manila Bay, around 60-70 km from Metro Manila, are the Natib and Mariveles stratovolcanoes (Figure 1A). Natib volcano $\left(14^{\circ} 43 \mathrm{~N}, 120^{\circ} 24 \mathrm{E}\right)$ is 1253 meters high with a base diameter of $26 \mathrm{~km}$. On the other hand, Mariveles volcano ( $14^{\circ} 30$ $\mathrm{N}, 120^{\circ} 30 \mathrm{E}$ ) is 1388 meters high with a base diameter of 22 kilometers. These two stratovolcanoes form the Bataan Peninsula and partly encloses Manila Bay (Figure 1B). Available age dates for Natib Volcano are 0.069-1.6 Ma (EBASCO 1977, 1977), 0.543.0 Ma (Wolfe, 1983), 20-59 ka (EBASCO 1977, 1977) (EBASCO, 1979), $27+0.63 \mathrm{ka}$ (Volentik et al., 2009) and 11.3-18 ka (Cabato et al., 2005). Deposits from Mariveles Volcano have dates of 0.19 4.1 Ma (Wolfe, 1983) and as young as $5 \mathrm{ka}$ (Siebert and Simkin, 2002).

Located south of the Zambales range, these stratovolcanoes are part of a volcanic chain called the Central Luzon Volcanic Arc, which are related to subduction along the Manila Trench (Catane et al., 2003). The most famous volcanoes related to this volcanic chain are the Pinatubo $(1486 \mathrm{~m})$ and Taal $(311 \mathrm{~m})$ volcanoes. Pinatubo, which erupted cataclysmically in 1991, is located north of Mount Natib. In between Mount Pinatubo and Mount Natib are the volcanoes Negron $(1506 \mathrm{~m})$ and Balikabok $(849 \mathrm{~m})$ (Figures 1C).

\section{METHODS}

96-h each of Doppler radar data from the Subic station for both the 2012 Habagat event (06 August 2012 00:00 UTC to 10 August 2012 00:00 UTC) and 2013 Habagat event (18 August 2012 00:00 UTC to 22 August 2012 00:00 UTC) are analyzed. The Subic doppler radar, operated and maintained by the PAGASA, has a 
temporal resolution of $9 \mathrm{~min}$ and spatial resolution of 1 degree by $500 \mathrm{~m}$. It is situated among the Zambales Mountain range in the municipality of Subic (see Figure 1). The country's biggest metropolis, Metro Manila, which suffered massive floods due to the enhanced rains, is covered by this radar. Besides considering recorded data, simulations using Weather Research and Forecasting (WRF) model were used to determine the extent of the Orographic Effect in generating heavy precipitation that inundated Metro Manila, adjacent suburbs and rural villages during the Habagat events of 2012 and 2013.

One factor that strengthened the Habagat was the presence of tropical cyclones northeast of the Philippines. Hovering over the Pacific Ocean, Typhoon Haikui of 2012 enhanced the South West Monsoon by pulling in moist air toward the land (Heistermann et al., 2013). A similar scenario, with a tropical storm located northeast of the Philippines was also present during the 2013 Habagat, with Tropical Storm Trami (local codename Maring) enhancing the monsoon. Comparisons between the two Habagat events are provided in the discussion.

The WRF model version 3.5.1 was used to simulate the effect of Natib and Mariveles volcanoes on moist air mass from the West Philippine Sea, drawn to the east-northeast by a tropical cyclone northeast of the Philippines from 6-9 August 2012 and 18-20 August 2013. The WRF is a non-hydrostatic mesoscale numerical weather prediction model used for both operational forecasting and atmospheric research. It is based on an Eulerian solver with a terrain following pressure coordinate. To simulate the effect of Mt. Natib and Mt. Mariveles on precipitation, two (2) simulation cases were conducted. One was a control run where topography was left unchanged while the second was a simulation run where the two volcanoes were removed. The simulation used a cloud-resolving $1 \mathrm{~km}$ grid scale, with terrain heights from the 30-arc second USGS global topography data set (Figure 3 ). The simulation domain in this study has horizontal resolutions of $25 \mathrm{~km}, 5 \mathrm{~km}$ and $1 \mathrm{~km}$ for each of the domains in a 3-way nested configuration centered at the Metropolitan Manila area. Vertical resolution includes 27 layers from surface to $10 \mathrm{mb}$, with higher resolution in the lower layers and allowed to run for $48 \mathrm{~h}$ prior to analysis for spin up. Meteorological factors are from the NCEP FNL reanalysis data. The main model options listed in Table 1 are the parameters used by the Philippine national weather bureau for its operational daily forecast.

\section{RESULTS}

\subsection{DOPPLER DATA}

During both Habagat events, the Subic Doppler radar was able to estimate precipitation up to $200 \mathrm{~km}$ radius from its location, including Metro Manila and vicinities. Blind spots in the southern sector and northern sector are due to blocked radar signals by mountain terrain (see Figure 4). Figure 4 shows 96h accumulation for 06-10 August 2012 and 18-22 August 2013. Plume-like patterns of high accumulated rainfall estimates are observed to emanate from the regions starting from near the summit of the Natib and Mariveles volcanoes toward its leeward side for both cases. The plume-like pattern indicating high accumulated estimated precipitation extends up to $80 \mathrm{~km}$ from the peaks. From the Doppler radar data, it can be noticed that the 2012 Habagat event had a more northeast trending rain scatter as opposed to the eastward rain scatter in 2013 (Figure 4). The alignment of the patterns indicates a steady wind direction over

\section{Table 1 | WRF model configuration.}

\begin{tabular}{ll}
\hline Process & Option \\
\hline Microphysics & Eta microphysics \\
Long wave radiation & RRTM \\
Short wave radiation & Dudhia \\
Boundary layer scheme & Yonsei University scheme \\
Cumulus parameterization & Kain-Fritsch scheme
\end{tabular}

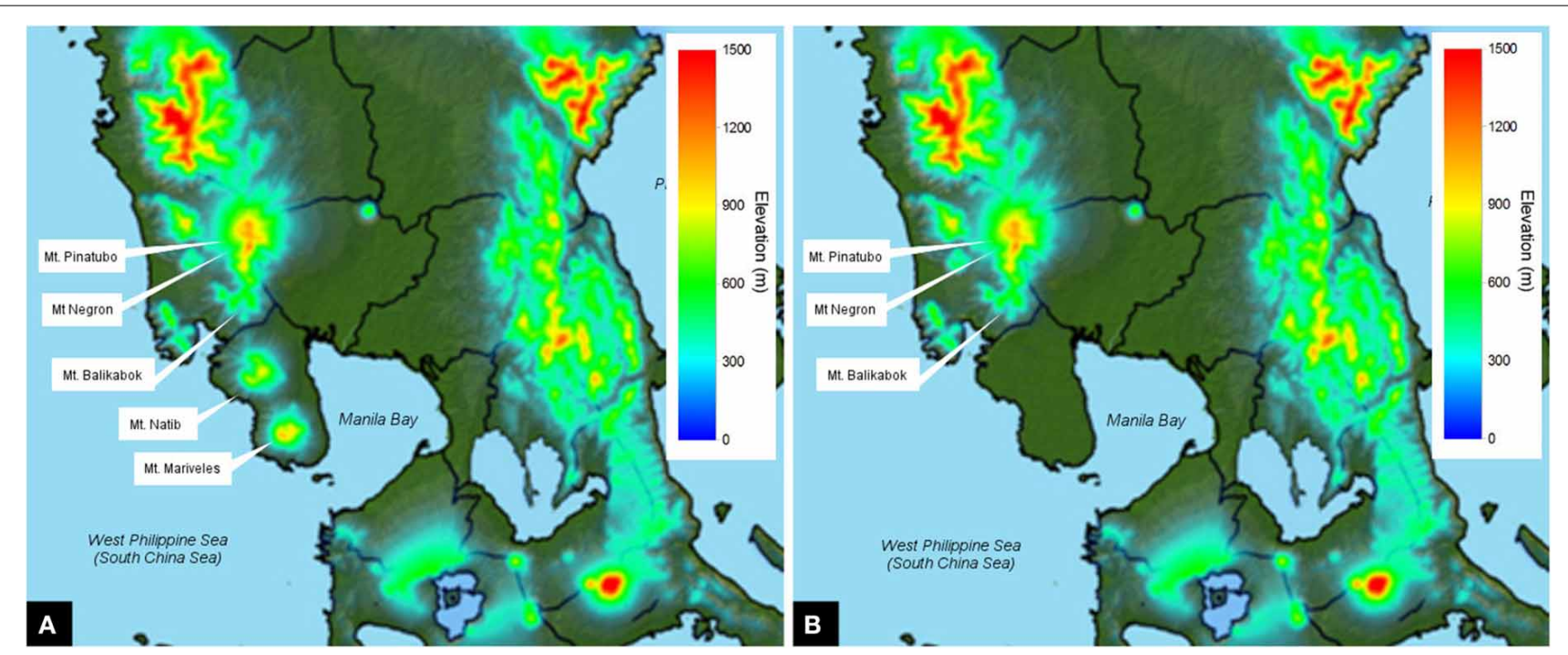

FIGURE 3 | Topography used in the WRF model (A) with Natib and Mariveles Volcanoes (B) without Natib and Mariveles volcanoes. 


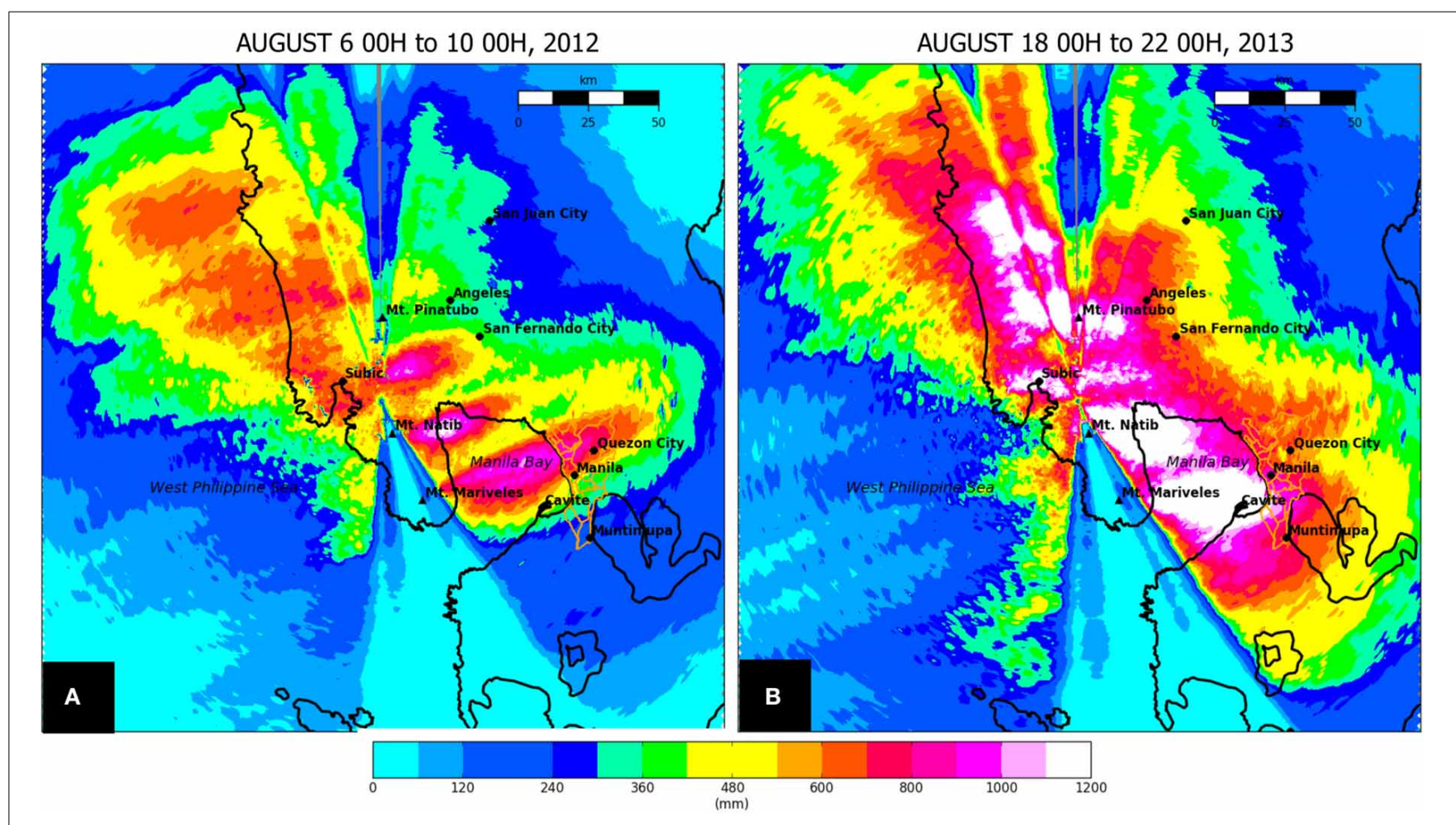

FIGURE 4 | Doppler accumulation for the (A) Habagat event of 2012 and (B) Habagat event of 2013. Plume-like patterns (dispersive tail) of high accumulated rainfall appear on the leeward side of the Mt. Natib and Mt. Mariveles volcanoes.

several days, consistent with the typical monsoon winds. Also noticeable in the plots are plume-like rainfall scatter that emanate from Mt. Mariveles and Mt. Natib and to a smaller degree from Mt. Balikabok and Mt. Pinatubo (see Figure 4). The rain scatter from Mt. Mariveles in particular falls mostly in Manila Bay but its extension is what reaches into Metro Manila.

\subsection{WRF SIMULATIONS}

The model runs of the WRF for both the Habagat 2012 and 2013 events show heavy precipitation on the windward side of Mount Natib and Mariveles (Figures 5A,C) a feature not seen in the simulation scenario when the two volcanoes are stripped off (Figures 5B,D). In addition to heavy precipitation due to the orographic effect in the windward side of Natib and Mariveles volcanoes, there is also more rainfall observed over Manila Bay and extended rain cloud distribution in the southern portion of Metro Manila.

When simulated in WRF for vertically-integrated rain water mixing ratio, which is the amount of rain water (in $\mathrm{kg}$ ) per volume of air (in kg), both Mt. Natib and Mt. Mariveles produced a trail of rain clouds (Figures 6A,C) which brought higher precipitation (Figures 5A,C) over Manila Bay and the western portions of Metro Manila. In these simulations, cloud trails emanate from Natib and Mariveles volcanoes extending toward Metro Manila. East of the metropolis where there are mountains, cloud trails are enhanced (right middle portion of Figures $6 \mathbf{A}, \mathbf{C}$ ). In the model runs where Natib and Mariveles volcanoes are stripped off, there is significantly less rain water in cloud trails over Manila Bay
(Figures 6B, D). Without Natib and Mariveles, the cloud trails only begin to form upon entering the mountainous region east of Metro Manila (right middle portion of Figure 6B). Mt. Pinatubo, which was not removed in the topography for the WRF simulation runs (case 1 and case 2), produced west- to east-directed cloud trails.

Apart from the updraft in the windward side of Mariveles volcano, the simulated vertical wind speed cross section along Mt. Mariveles also produces a wave breaking region with as much as $2.4 \mathrm{~ms}^{-1}$ upward speed. This updraft region resembles a lee wave, referred to as a "dispersive tail" of nonhydrostatic waves by Smith (1979). According to Cotton et al. (2011) the size of the edifice determines the maximum amplitude of the nonhydrostatic waves and can be observed at low levels on the leeward side of a mountain. This dispersive tail is maintained for appreciable distance downwind. In the case of Mariveles and Natib volcanoes, the dispersive tail was maintained for more than 80 kilometers reaching the heavily populated capital of the Philippines. Dispersive tails of rain clouds formed from this orographic updraft are clearly seen in the radar images in Figure 4.

\section{DISCUSSION}

Recently acquired Doppler Radar stationed at Subic, Zambales has allowed the study of mesoscale weather events, such as the intense rains that appear to emanate from the Natib and Mariveles volcanoes. Previously, such rain cloud patterns that form during the southwest monsoon season could not be viewed and studied in detail. All that was known was tropical cyclones, especially 


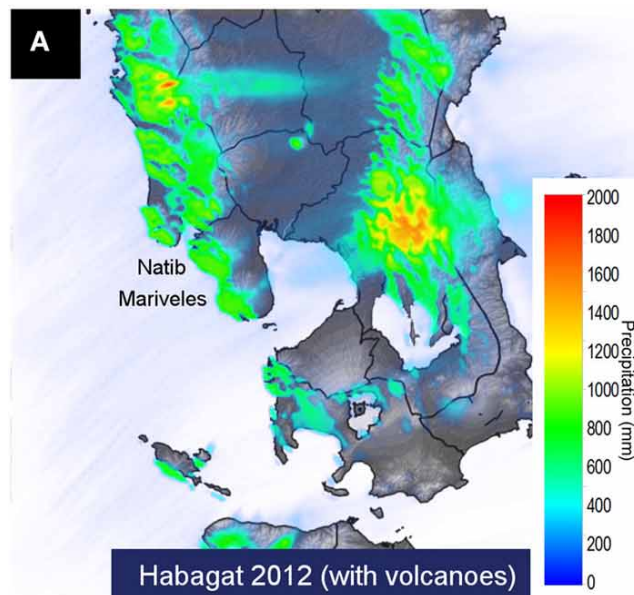

c

FIGURE 5 | Simulated 1 km grid-scale accumulated ground precipitation in Manila bay area from 6 August $0 Z$ to 10 August $0 Z 2012$ during Habagat 2012 for (A) topography with Natib and Mariveles volcanoes

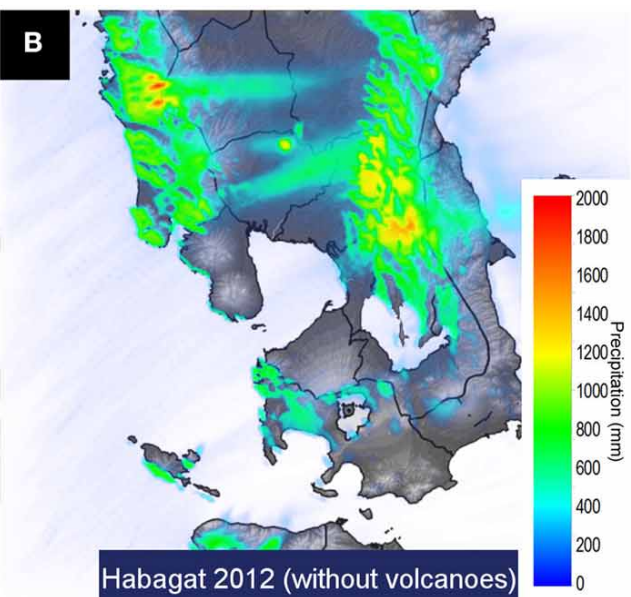

D

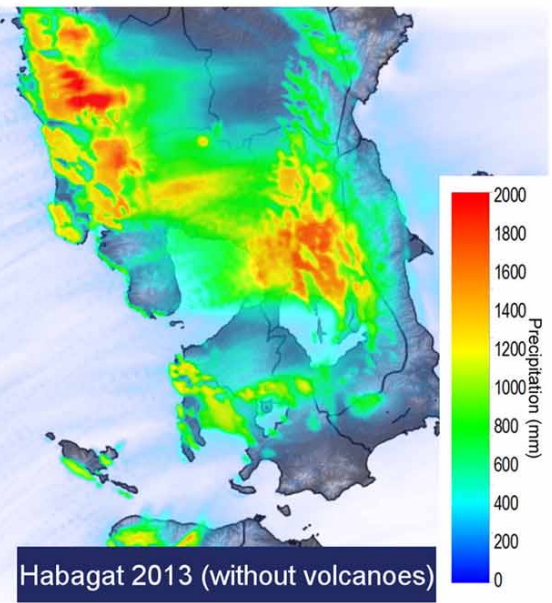

and (B) without Natib and Mariveles volcanoes. The bottom panel shows simulations from 18 August $0 Z$ to 22 August OZ during Habagat 2013 for (C) with the volcanoes and (D) without the volcanoes. those passing through the northeast side of the Philippine archipelago, enhanced the southwest monsoon and bring forth heavy rains to the country's western section. This process must have taken place for thousands of years in the region but was only observed recently because of the availability of Doppler data.

Simulations of the accumulated water mixing ratio using the WRF corroborate the observations from Doppler radar, showing that the two volcanoes are major sources of rain clouds during the Habagat 2012 and 2013 events (Figures 6A,C, respectively). Without the volcanoes (Figures 6B,D) there are no major rain clouds formed. A better view of the dispersive tail of the Habagat event is seen as a snapshot in time of the WRF simulation (Figure 7).

The Doppler observations (see Figure 4) and the WRF models (Figures 5, 6) show the Natib and Mariveles stratovolcanoes as the source of the dispersive tail of clouds that bring forth heavy rains. Some also emanate from the more northern peaks of Pinatubo and Negron volcanoes, but are significantly less than those generated from the summit of Natib and Mariveles. It is unclear as to why the two volcanoes in the southern part of the mountain range generated more rain-laden clouds that move out to Metro Manila. However, since atmospheric moisture is an important element in orographic lift and initiation of convective cloud development, we suspect that there was more moist air in the region of Natib and Mariveles during the Habagat 2012 and Habagat 2013 events. This is supported by Multi-Functional Transport Satellite (MTSAT) images that depict high atmospheric moisture west of the Bataan Peninsula (Figure 8).

Moist air flowing from the southwest to the northeast encountered the two stratovolcanoes in the Bataan Peninsula during the Habagat 2012 and 2013 events and were forced to rise and cool, thereby initiating convection. Known as the orographic effect, clouds formed through this process did not remain in the windward side of volcanoes but were pulled by the cyclones located northeast of the Philippines (Figure 8). Strong winds formed the dispersive tail of clouds crossing Manila Bay up to Metro Manila.This kind of phenomenon where volcanoes generate excessive rainfall in the leeward side rather than the windward side is not documented in the literature on volcanic hazards. In cases where large urban areas are in the windward side of 


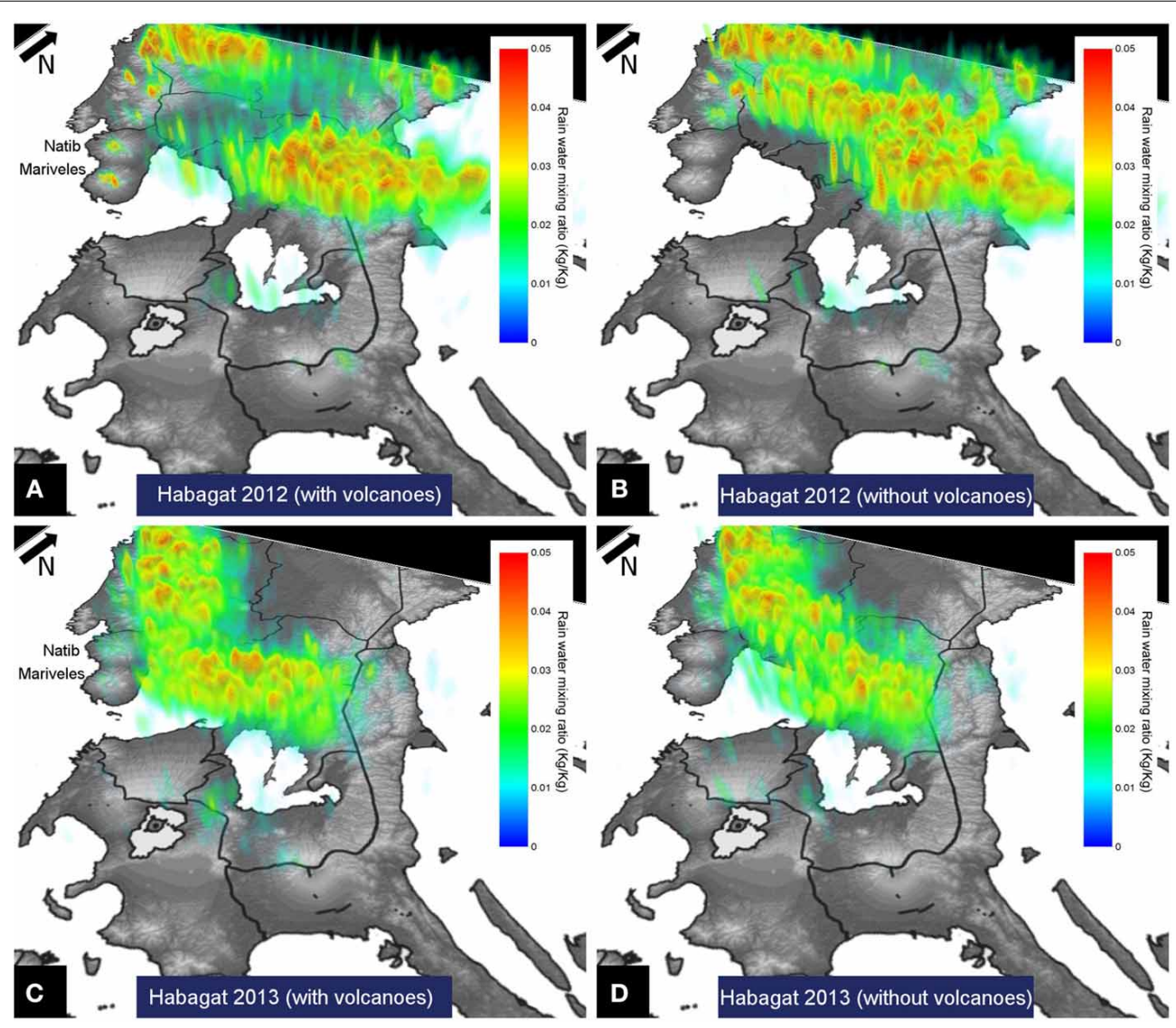

FIGURE 6 | Simulated vertically-integrated accumulated rain water mixing ratio for (A) Habagat 2012 with volcanoes, (B) Habagat 2012 without volcanoes, (C) Habagat 2013 with volcanoes, (D) Habagat 2013 without volcanoes.
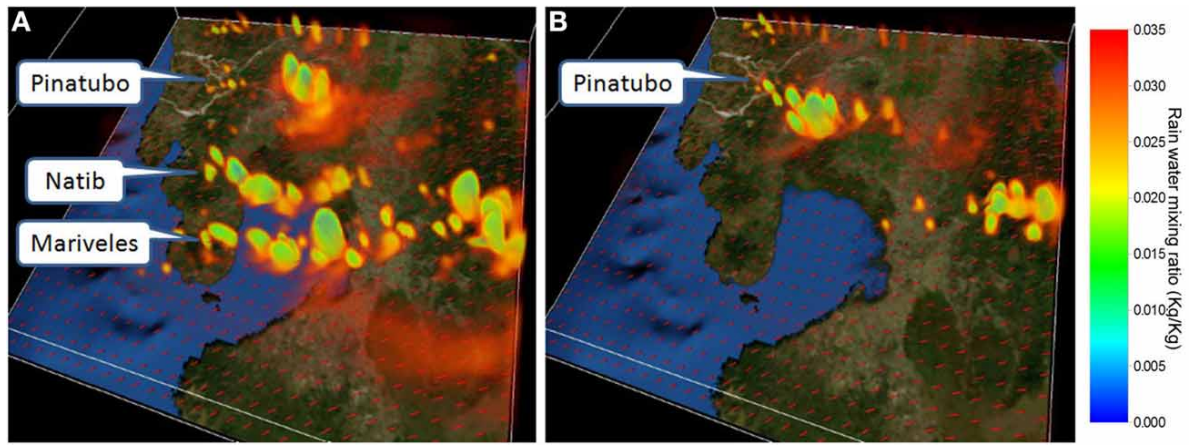

FIGURE 7 | Snapshot in time of the simulated accumulated rain water mixing ratio for (A) case 1 and (B) case 2 from 19 August $201300 Z$ to 19 August 2013 00Z. The vectors represent the wind direction.

volcanoes, heavy monsoon rains may ensue and have destructive impacts, a hazard phenomenon linked with the volcano's shape and size.

The observed interaction of stratovolcanoes with the monsoon in the Philippines has broad implications worldwide. Monsoons, characterized by rainfall and seasonal reversals of prevailing winds are a global phenomenon and occurs in three main continental sectors. These are the Asia-Australia, Africa, and American continents. Based on the monsoon's seasonal movement, they are further subdivided into regions (Saha, 2010) as shown in Table 2.

There are many regions listed in Table 2 that may have monsoon rains potentially enhanced by volcanoes than can generate massive floods. Some examples in Southeast Asia are the volcanoes in Negros and Camiguin Islands, Philippines; those in Java, south of the heavily populated city of Jakarta; and volcanoes in the central part of Myanmar. In North Africa, volcanoes 


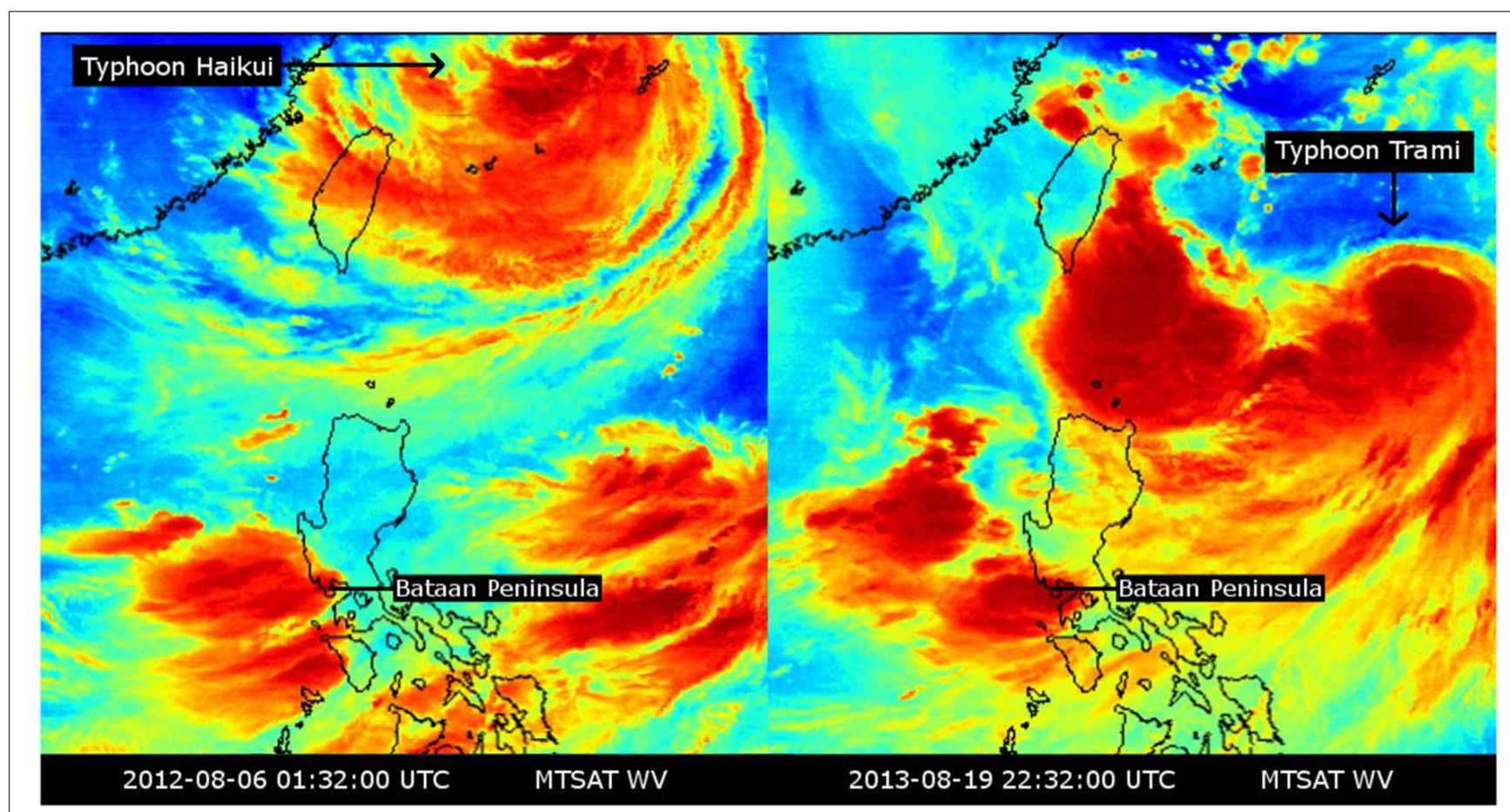

FIGURE 8 | MTSAT Water Vapor images showing a snapshot of the enhanced monsoon of 2012 and 2013. The figure shows the locations of the typhoons that pulled in moist air toward the Bataan Peninsula.

Table 2 | Monsoon regions three main continental sectors (Saha, 2010).

\begin{tabular}{lll}
\hline $\begin{array}{l}\text { Continental sector } \\
\text { sector }\end{array}$ & $\begin{array}{l}\text { Monsoon region } \\
\text { region }\end{array}$ & $\begin{array}{l}\text { Countries / Region } \\
\text { affected }\end{array}$ \\
\hline Asia-Australia & Region I & $\begin{array}{l}\text { Indian subcontinent and } \\
\text { adjoining Southeast Asia } \\
\text { Eastern Asia including } \\
\text { China, Korea, and Japan } \\
\end{array}$ \\
& Region II & $\begin{array}{l}\text { Maritime continent } \\
\text { including Indonesia and }\end{array}$ \\
& Region III & Philippines \\
Africa & Region V & $\begin{array}{l}\text { North and South Africa } \\
\text { South America }\end{array}$ \\
America & Region VII & $\begin{array}{l}\text { Central America and } \\
\text { adjoining States of }\end{array}$ \\
& & Southwestern Northwest
\end{tabular}

in the Cameroon Volcanic Line (CVL) are potential candidates to investigate for this type of mesoscale weather phenomenon. The western part of South and North America are in the Pacific Ring of Fire and lined with volcanoes where many cities are located. Guatemala City for example is in the shadow of stratovolcanoes, which may enhance monsoon and cyclone-related rains and trigger not only floods but also landslides, including lahars. Volcanoes also need not be composite cones nor active in order to enhance monsoon rains. There are many inactive volcanoes in southwest United States such as those found in the San Francisco volcanic and White Mountain volcanic field in the Mogollon rim (i.e.,
Kendrick Peak, $3175 \mathrm{~m}$ and Agassiz Peak, $3766 \mathrm{~m}$ ) that can bring heavy rainfall to cities in Arizona and New Mexico.

During the cataclysmic eruption of Pinatubo on 15 June 1991, typhoon Yunya (local name Diding) passed within 75 kilometers of the exploding volcano and increased the weight of tephra accumulations and the destruction they caused. The typhoon also spread ash over much wider areas than would have otherwise received ash (Oswalt et al., 1997). Ash with thickness values of 4-5 mm was deposited in Metro Manila. The possibility to have volcanic activity from Natib and Mariveles volcanoes can bring tephra east toward Metro Manila during a heavy rainfall monsoon event is not remote since these stratovolcanoes are classified by Phivolcs as potentially active.

\section{CONCLUSIONS}

Extreme rainfall with consequent floods is not listed as a hazard associated with volcanoes. Although the orographic effect is known in volcanoes to generate more rainfall in the windward side and deplete moisture in the leeward side, enhanced rains and cloud trails with intense rainfall that travel for more than $80 \mathrm{~km}$ beyond the leeward slopes of the volcano are not documented. The case of the lethal 2012 and 2013 Habagat floods where Natib and Mariveles volcanoes enhanced precipitation is remarkable, delivering more than $1000 \mathrm{~mm}$ (see Figure 2) of southwest monsoon rain over a highly populated metropolis. The volcanoes' shape and size, which is formed through numerous eruptions during a volcano's lifespan, influence the formation of clouds that deliver extreme rains during the southwest monsoon season resulting in destructive floods in urban areas located in the 
lee- ward side of the volcano. The description of the destructive impacts of this phenomenon should be enough to consider orography and associated dispersion of cloud trails in the list of the causes of volcano-associated hazards.

The presence of the volcanoes west of Metro Manila enhances the rains during the southwest monsoon season and will continue to threaten the rapidly growing population of the metropolis. In part, the reason for the heavy rains is due to the presence of Natib and Mariveles volcanoes. WRF simulations in this study show that without these stratovolcanoes, rains in Metro Manila during the Habagat 2012 and 2013 flood events would be 33\% less.

Many volcanoes situated near urban centers, which have similar weather as the Philippines may also experience the same orographic and dispersive tail of nonhydrostatic waves phenomena (Smith, 1979), heretofore not associated with massive volcanic cones. Because of its severity and flood impact especially to large urban areas, it is worthy of further investigation in the Philippines and elsewhere to better understand the phenomenon for possible hazard mitigating solutions, if any. Future work may include higher resolution WRF simulations and the effects of ash on rainfall.

\section{ACKNOWLEDGMENTS}

We thank DOST Project NOAH for funding this work and PAGASA for access to the doppler radar data.

\section{REFERENCES}

Abon, C., David, C., and Pellejera, N. (2011). Reconstructing the tropical storm ketsana flood event in marikina river, philippines. Hydrol. Earth Syst. Sci. 15, 1283-1289. doi: 10.5194/hess-15-1283-2011

Ahasan, M., Chowdhary, M., and Quadir, D. (2010). Variability and trends of summer monsoon rainfall over bangladesh. J. Hydrol. Meteorol. 7, 1-17. doi: 10.3126/jhm.v7i1.5612

Cabato, J., Rodolfo, K., and Siringan, F. (2005). History of sedimentary infilling and faulting in subic bay, philippines revealed in high-resolution seismic reflection profiles. J. Asian Earth Sci. 25, 849-858. doi: 10.1016/S1367-9120(04)00170-1

Catane, S., Listanco, E., Corpuz, E., Lagmay, A. M. F., Bornas, M., Cabria, H., et al. (2003). "Active volcanoes in the Philippines, Mayon, Pinatubo, Taal," in International Union of Geodesy and Geophysics Field Trip Guidebook, A5:1-A5:66

Cotton, W., Bryan, G., and van den Heever, S. (2011). Storm and Cloud Dynamics: The Dynamics of Clouds and Precipitating Mesoscale Systems. Oxford, UK: Academic Press.

Cox, W. (2011). The Evolving Urban Form. Manila: New Geography. Available Online at: http://www.newgeography.com/content/002198-the-evolvingurban-form-manila

Crimmins, M. (2006). Arizona and the North American Monsoon System. Tuczon, AZ: The University of Arizona College of Agriculture and Life Sciences.

EBASCO. (1977). Preliminary Safety Analysis Report, Philippine Nuclear Power Plant 1.Technical Report, Philippine Atomic Energy Commission Open-File Report and Response to Questions. Manila: Philippine Atomic Energy Commission.

EBASCO. (1979). Evidence Substantiating the Incredibility of Volcanism on the West Flank of mt. Natib, and the Assessment of Volcanic Hazards at Napot Point.Response to Philippine Atomic Energy Commission Question 3. Manila: Philippine Atomic Energy Commission.

Hales, J. Jr. (1974). Southwestern united states summer monsoon sourcegulf of mexico or pacific ocean? J. Appl. Meteorol. doi: 10.1175/15200450(1974)013<0331:SUSSMS >2.0.CO;2

Heistermann, M., Crisologo, I., Abon, C., Racoma, B., Jacobi, S., Servando, N. T., et al. (2013). Brief communication: Using the new philippine radar network to reconstruct the habagat of august 2012 monsoon event around metropolitan manila. Hydrol. Earth Syst. Sci. 13, 653-657. doi: 10.5194/nhess-13-653-2013

Holton, J., Curry, J., and Pyle, J. (eds.). (2003). "Monsoons," in Encyclopedia of the Atmospheric Sciences (Oxford, UK: Elsevier Science Ltd.), 1365-1400.
Hutchison, C. (1989). Geological Evolution of South-East Asia. Oxford: Oxford University Press.

Knabb, R., Rhome, J., and Brown, D. (2005). Tropical Cyclone Report, Hurricane Katrina. Miami, FL: National Hurricane Center Reports.

Kripalani, R., Kulkarni, A., Sabade, S., and Khandekar, M. (2003). Indian monsoon variability in a global warming scenario. Nat. Hazards. 29, 189-206. doi: 10.1023/A:1023695326825

Lagmay, A. M. F. (1993). Geochemistry of Hypabyssal Dike Intrusions and Mafic Cumulates in the San Antonio Massif. M.Sc. Thesis, National Institute of Geological Sciences, University of the Philippines.

Lagmay, A. M. F., Rodolfo, R., and Bato, G. (2010). The perfect storm: floods devastate manila. Earth 55, 50-55.

Lau, K., Ding, Y., Wang, J., Johnson, R., Keenan, T., Cifelli, R., et al. (2000). A report of the field operations and early results of the south china sea monsoon experiment (scsmex). Bull. Am. Meteorol. Soc. 81, 1261-1270. doi: 10.1175/1520-0477(2000)081<1261:AROTFO > 2.3.CO;2

NDRRMC. (2012). Effects of Southwest Monsoon Enhanced by Typhoon Haikui. Metro Manila: National Disaster Risk Reduction and Management Council Sitrep No. 20.

NDRRMC. (2013). Effects of Southwest Monsoon (Habagat) Enhanced by Tropical Storm Maring. Quezon City: National Disaster Risk Reduction and Management Council Sitrep No. 20.

NOAA. (2004). The North American Monsoon: Reports to the Nation on our Changing Planet. Technical report, NOAA.

Oswalt, J. S., Nichols, W., and O’Hara, J. (1997). "Fire and Mud Eruptions and Lahars of Mount Pinatubo, Philippines," in Meteorological Observations of the 1991 Mount Pinatubo Eruption (Quezon City: Philippine Institute of Volcanology and Seismology and University of Washington Press), 625-636.

PAGASA. (2013). Definition of Terms: Philippine Atmospheric Geophysical and Astronomical Services Administration. Available online at: http://kidlat.pagasa. dost.gov.ph/cab/define.htm

Phivolcs. (2013). Philippine Institute of Volcanology and Seismology List of Active, Potentially Active and Inactive Volcanoes. Available online at: http://www. phivolcs.dost.gov.ph

Roth, D. (2008). Hurricane Katrina - August 24-September 1, 2005. Technical report, Hydrometeorological Prediction Center.

Saha, K. (2010). Tropical Circulation Systems and Monsoons. Berlin; Heidelberg: Springer.

Siebert, L., and Simkin, T. (2002). Volcanoes of the World: an Illustrated Catalog of Holocene Volcanoes and their Eruptions. Washington, DC: Smithsonian Institution, Global Volcanism Program Digital Information Series, GVP-3.

Smith, R. (1979). The influence of mountains on the atmosphere. Adv. Geophys. 21, 108-109.

Volentik, A. C., Connor, C., Connor, L., and Bonadonna, C. (2009). "Volcanic and tectonic hazard assessment for nuclear facilities," in Aspects of Volcanic Hazards Assessment for the Bataan Nuclear Power Plant, Philippines: Luzon Peninsula, (Cambridge: Cambridge University Press), 229-256. doi: 10.1017/CBO9780511635380.010

Whiteman, C. (2000). Mountain Meteorology: Fundamentals and Applications Madison, NY: Oxford University Press Inc.

Wolfe, J. (1983). Origin of the philippines by accumulation of allochthons. Philip. Geol. 37, 16-33.

Conflict of Interest Statement: The authors declare that the research was conducted in the absence of any commercial or financial relationships that could be construed as a potential conflict of interest.

Received: 05 August 2014; accepted: 04 December 2014; published online: 13 January 2015 .

Citation: Lagmay AMF, Bagtasa G, Crisologo IA, Racoma BAB and David CPC (2015) Volcanoes magnify Metro Manila's southwest monsoon rains and lethal floods. Front. Earth Sci. 2:36. doi: 10.3389/feart.2014.00036

This article was submitted to Volcanology, a section of the journal Frontiers in Earth Science.

Copyright (c) 2015 Lagmay, Bagtasa, Crisologo, Racoma and David. This is an openaccess article distributed under the terms of the Creative Commons Attribution License (CC BY). The use, distribution or reproduction in other forums is permitted, provided the original author(s) or licensor are credited and that the original publication in this journal is cited, in accordance with accepted academic practice. No use, distribution or reproduction is permitted which does not comply with these terms. 